\title{
Determination of Metallic Contaminants in Human Recombinant Erythropoietin (EPO) Formulations by Adsorptive Cathodic Stripping Voltammetry and UV Photo-Decomposition of Samples
}

\author{
Leandro M. de Carvalho, ${ }^{a} *$ Júlia C. Garmatz, ${ }^{a}$ Cristiane Spengler, ${ }^{a}$ \\ Paulo C. do Nascimento, ${ }^{a}$ Denise Bohrer, ${ }^{a}$ Cibele M. Canabarro, ${ }^{a}$ Solange C. Garcia ${ }^{b}$ \\ and Marcelo B. da Rosa ${ }^{c}$
}

${ }^{a}$ Departamento de Química, Universidade Federal de Santa Maria, CP 5051, 97105-970 Santa Maria-RS, Brazil

${ }^{b}$ Departamento de Análises Clínicas, Faculdade de Farmácia, Universidade Federal do Rio Grande do Sul, 90610-000 Porto Alegre-RS, Brazil

'Departamento de Química, Universidade Federal do Pampa (UNIPAMPA), 96412-420 Bagé, RS, Brazil

\begin{abstract}
A contaminação de pacientes com insuficiência renal por espécies metálicas pode estar associada a presença destes na medicação empregada durante o tratamento. Dentre os possíveis contaminantes estão metais nefrotóxicos tais como alumínio, cromo e níquel. No presente trabalho, a presença de $\mathrm{Al}, \mathrm{Cr}$ e $\mathrm{Ni}$ como contaminantes em formulações de eritropoetina (EPO) foi investigada através da otimização de métodos analíticos empregando a voltamétria adsortiva de redissolucao catódica (AdCSV) associada a foto-decomposição de amostras com radiação UV. A irradiação UV de amostras acidificadas de EPO pelo período de 2 a 3 horas na presença de $\mathrm{H}_{2} \mathrm{O}_{2}$ possibilitou a decomposição eficiente da amostra e a determinação dos contaminantes por AdCSV sem a interferência da matriz. O método otimizado foi aplicado na determinação dos metais em formulações comerciais de EPO utilizadas rotineiramente no tratamento da anemia em pacientes com insuficiência renal crônica. Os níveis de contaminação encontrados nas amostras estudadas variaram de 420,2 a 840,5 $\mathrm{ng} \mathrm{mL}^{-1}$ (RSD 2-5\%) para o Al, de 12,0 a 40,0 ng mL $\mathrm{mL}^{-1}$ (RSD 2-6\%) para o $\mathrm{Cr}$ e de 4,1 a 8,2 $\mathrm{ng} \mathrm{mL}^{-1}$ (RSD 3-8\%) para o Ni. Os resultados obtidos por AdCSV foram comparáveis aos obtidos por espectrometria de absorção atômica com atomização em forno de grafite (GFAAS). A contaminação de formulações EPO com Al, Cr e Ni mostrou ser uma fonte de contaminação importante para pacientes anêmicos com insuficiencia renal crônica.
\end{abstract}

The contamination of renal failure patients by metals can be associated to the presence of toxic metals in the medication, since they can be absorbed by the organism. Among the possible contaminants, there are nephrotoxic metals such as aluminum, chromium and nickel. In the present work, the presence of $\mathrm{Al}, \mathrm{Cr}$ and $\mathrm{Ni}$ as contaminants in erythropoietin formulations (EPO) was investigated by optimizing the adsorptive cathodic stripping voltammetric (AdCSV) method and the photo-decomposition of samples by UV irradiation. The UV irradiation of acidified EPO samples from 2 to $3 \mathrm{~h}$ in the presence of $\mathrm{H}_{2} \mathrm{O}_{2}$ allowed the efficient sample decomposition and the determination of the contaminants by AdCSV without matrix interferences. The method was applied for the determination of the metals in commercial EPO formulations used routinely in the treatment of anemia in patients undergoing chronic renal failure. The contamination levels determined in the samples ranged from 420.2 to $840.5 \mathrm{ng} \mathrm{mL}^{-1}$ (RSD 2-5\%) for Al, 12.0 to $40.0 \mathrm{ng} \mathrm{mL}^{-1}$ (RSD 2-6\%) for Cr and 4.1 to $8.2 \mathrm{ng} \mathrm{mL}^{-1}$ (RSD 3-8\%). The results obtained by AdCSV were in good agreement with those obtained by the comparative GFAAS measurements. The contamination of EPO formulations with $\mathrm{Al}, \mathrm{Cr}$ and $\mathrm{Ni}$ was shown to be a serious contamination source for anemic patients undergoing chronic renal failure.

Keywords: adsorptive cathodic stripping voltammetry, UV irradiation, photo-decomposition, erythropoietin

*e-mail: lemacarvalho@gmail.com 


\section{Introduction}

Chronical renal failure causes a wide variety of metabolic disturbances which affect almost every organ in the body system. Despite continuous improvement in dialysis treatment, many organ functions are still impaired. Furthermore, multiple drugs are frequently used for the underlying diseases and uremic complications. ${ }^{1}$ The possibility of trace metal contamination in various medications and effects of medications on the metabolism of trace metals have been increasingly studied in the last years. In previous works, we showed that the contamination of hemodialysis patients by toxic metals such as $\mathrm{Al}, \mathrm{As}, \mathrm{Zn}$, $\mathrm{Pb}, \mathrm{Cd}$ and $\mathrm{Tl}$ can be related to their presence in dialysis concentrates or water used for the preparation of dialysis fluids. ${ }^{2-9}$ Besides, Lee and co-workers ${ }^{1}$ reported that the contamination of hemodialysis patients could be also related to the medication used in the treatment of anemia, such as the renal antianemic human recombinant erythropoietin (EPO).

EPO is a renal antianemic medicament used in the treatment of renal failure or chronic renal disease caused by diminished EPO production in the kidneys. It is a glycoprotein synthetically produced by the recombinant DNA technology, which contains 165 aminoacids in a sequence identical to the endogen human EPO. Its biological activity is identical to the endogen hormone and it is administered to renal failure anemic patients normally by intravenous injection of a $50 \mathrm{IU} / \mathrm{kg}$ dose, three times a week. ${ }^{10}$ In the pharmaceutical market, formulations are commercialized as lyophilized powder or intravenous solution in the concentrations $1000 \mathrm{IU}, 2000 \mathrm{IU}, 3000 \mathrm{IU}$, $4000 \mathrm{IU}$ or $10000 \mathrm{IU}$ of recombinant EPO. Furthermore, non-active components, such as glycine, human albumin, sodium phosphates and sodium chloride are also present. ${ }^{11}$

The toxicological effects of inorganic contaminants vary among the species. It is well known that the aluminium accumulation in the body is related to neurological disorders and damage of osteous structure of patients. ${ }^{10,12}$ Chromium is considered an essential trace element. However, high levels of chromium in the body can lead to increasing vascular damage in hemorragy cases and cerebral trombosis. ${ }^{12}$ Nickel, at small concentrations, is considered an important element in the human body as well. However, at elevated levels, it is very toxic and can lead to intestinal irritation, neurological disorders, cardiovascular alterations, and allergic reactions, such as dermatitis, chronic rhinitis and asthma. Furthermore, high levels of nickel in the human body can bring serious consequences leading to necroses and lung cancer. ${ }^{12}$

The contamination of renal failure patients by toxic metals can be strongly related to the presence of elements as contaminants in the medications used in the treatment, since they can be absorbed by the patient organism. The problem is aggravated by the reduced capacity of these patients in eliminating the toxic species from the body. The level of contamination in theses cases depends strongly on the quality of the medication administered during the treatment. Therefore, the existence of analytical methods, which allow the quality control of medicaments used in the treatment of chronic renal failure patients, is relevant to the clinical area and should be systematically studied.

The determination of metals by stripping voltammetry is very sensitive and it is well described in the literature. ${ }^{13,14}$ However, in complex matrices, such as EPO formulations, metallic species are normally bound to the organic components of the matrix. ${ }^{15}$ The UV irradiation for the photo-decomposition of samples is often employed in combination with the voltammetric determination of metals. Since the method normally uses small amounts of reagents (few $\mu \mathrm{L}$ of acids and $\mathrm{H}_{2} \mathrm{O}_{2}$ ) for the photodecomposition, it eliminates the matrix interference without contaminating the sample before the analysis. ${ }^{16}$

This paper describes the determination of some nephrotoxic metals, such as $\mathrm{Al}, \mathrm{Cr}$ and $\mathrm{Ni}$, in commercial formulations of EPO by using AdSV methods and UV photo-decomposition of the samples. The methods are based on the AdSV determination of $\mathrm{Al}$ in the presence of solochrome violet RS (SVRS), Cr in the presence of diethylenetriaminepentaacetic acid (DTPA) and nickel in the presence of dimethylglyoxime (DMG) as organic ligands. The metals were determined in EPO samples after optimization of a pretreatment step by using UV irradiation in the presence of $\mathrm{H}_{2} \mathrm{SO}_{4}$ and $\mathrm{H}_{2} \mathrm{O}_{2}$. The method (UV irradiation + AdCSV determination) allowed the rapid and sensitive determination of $\mathrm{Al}, \mathrm{Cr}$ and $\mathrm{Ni}$ at $\mathrm{ng} \mathrm{mL} \mathrm{m}^{-1}$ levels in different EPO formulations used in the treatment of anemic patients undergoing chronic renal failure.

\section{Experimental}

\section{Apparatus}

Voltammetric measurements were performed using a Metrohm 693 VA Processor in combination with a 694 VA Stand (all from Metrohm, Herisau, Switzerland). The three-electrode configuration was consisted of the hanging mercury drop electrode (HMDE) as working electrode, an $\mathrm{Ag} / \mathrm{AgCl}\left(3 \mathrm{~mol} \mathrm{~L}^{-1} \mathrm{KCl}\right)$ reference electrode and a platinum wire as auxiliary electrode. The surface area of HMDE was $0.6 \mathrm{~mm}^{2}$. In differential pulse stripping voltammetric (DPCSV) measurements, scans were performed with a 
pulse amplitude of $-50 \mathrm{mV}$, a pulse duration of $40 \mathrm{~ms}$ and a scan rate of $20 \mathrm{mV} \mathrm{s}^{-1}$. Scans were also preceded by stirred deposition (2000 rpm) at the HMDE.

Graphite furnace atomic absorption spectrophotometric (GFAAS) comparative measurements of $\mathrm{Al}, \mathrm{Cr}$ and $\mathrm{Ni}$ were performed using an AAS spectrophotometer ZEEnit 600 (Analytik Jena, Jena, Germany) with Zeeman background correction. The experimental conditions for the determinations of $\mathrm{Al}, \mathrm{Cr}$ and $\mathrm{Ni}$ are described in Table 1.

UV photo-decomposition experiments were performed using a Metrohm UV digestor (Model 705, Metrohm, Herisau) with a high-pressure mercury lamp of 500W. Comparative UV photo-decomposition experiments were performed in a home-made UV digestor with a high-pressure mercury lamp of $400 \mathrm{~W}$ used for public illumination, as described elsewhere..$^{15}$ All UV photodecomposition experiments were performed at $85 \pm 3{ }^{\circ} \mathrm{C}$.

Table 1. Experimental conditions used in the determination of $\mathrm{Al}, \mathrm{Cr}$ and Ni by GFAAS

\begin{tabular}{ccccc}
\hline Metal & $\begin{array}{c}\lambda \\
(\mathrm{nm})\end{array}$ & $\begin{array}{c}\text { Bandwidth } \\
(\mathrm{nm})\end{array}$ & $\begin{array}{c}\text { Current } \\
(\mathrm{mA})\end{array}$ & $\begin{array}{c}\text { Sample volume } \\
(\mu \mathrm{L})\end{array}$ \\
\hline $\mathrm{Al}$ & 309.3 & 0.8 & 6.0 & 20 \\
$\mathrm{Cr}$ & 357.9 & 0.8 & 4.0 & 20 \\
$\mathrm{Ni}$ & 232.0 & 0.2 & 5.0 & 20 \\
\hline
\end{tabular}

Temperature programs

\begin{tabular}{ccccccc} 
& \multicolumn{2}{c}{ Drying } & \multicolumn{2}{c}{ Pyrolysis } & \multicolumn{2}{c}{ Atomization } \\
& $\begin{array}{c}\text { Temp. } \\
\left({ }^{\circ} \mathrm{C}\right)\end{array}$ & $\begin{array}{c}\text { time } \\
(\mathrm{s})\end{array}$ & $\begin{array}{c}\text { Temp. } \\
\left({ }^{\circ} \mathrm{C}\right)\end{array}$ & $\begin{array}{c}\text { time } \\
(\mathrm{s})\end{array}$ & $\begin{array}{c}\text { Temp. } \\
\left({ }^{\circ} \mathrm{C}\right)\end{array}$ & $\begin{array}{c}\text { time } \\
(\mathrm{s})\end{array}$ \\
\hline $\mathrm{Al}$ & $90 / 105 / 34 / 25 /$ & 1300 & 14.8 & 2450 & 4.0 \\
& $110 \quad 12.5$ & & & & \\
$\mathrm{Cr}$ & $90 / 105 / 34 / 25 /$ & 950 & 13.4 & 2450 & 6.2 \\
& $110 \quad 12.5$ & & & & \\
$\mathrm{Ni}$ & $90 / 105 / 34 / 25 /$ & 1100 & 14.0 & 2350 & 6.0 \\
& $110 \quad 12.5$ & & & & \\
\hline
\end{tabular}

\section{Reagents and solutions}

All chemicals were of analytical grade purity. Water was purified by a Milli-Q Ultra Pure Water System (Millipore, Bedford, MA, USA). All chemicals were of analyticalreagent grade. Solochrome violete RS (SVRS) and diethylenetriaminepentaacetic acid (DTPA) were obtained from Acros Organics (Morris Plains, NJ, USA). 30\% (m/v) $\mathrm{H}_{2} \mathrm{O}_{2}, 37 \%(\mathrm{~m} / \mathrm{v})$ hydrochloric acid, $98 \%(\mathrm{~m} / \mathrm{v})$ sulfuric acid and dimethylglyoxime (DMG) were obtained from Merck (Darmstadt, Germany). All aqueous solutions were prepared with distilled and deionized water, which was further purified by a Milli-Q high purity water device. Metal stock solutions containing $1.00 \pm 0.02 \mathrm{~g} \mathrm{~L}^{-1}$ in $0.5 \mathrm{~mol} \mathrm{~L}^{-1}$ $\mathrm{HNO}_{3}$ were prepared from $\mathrm{Al}\left(\mathrm{NO}_{3}\right)_{3} \cdot 9 \mathrm{H}_{2} \mathrm{O}, \mathrm{Cr}\left(\mathrm{NO}_{3}\right)_{3} \cdot 9 \mathrm{H}_{2} \mathrm{O}$ and $\mathrm{Ni}\left(\mathrm{NO}_{3}\right)_{2}$ (Merck, Darmstadt, Germany). The $\mathrm{Al}, \mathrm{Cr}$ and Ni stock solutions were standardized by complexometric titration with EDTA (Merck, Darmstadt, Germany). ${ }^{17,18}$ $1 \mathrm{mg} \mathrm{L}^{-1}$ working stock solutions of $\mathrm{Ni}(\mathrm{II})$ and $\mathrm{Cr}(\mathrm{VI})$ were obtained by suitable dilutions of the $1000 \mathrm{mg} \mathrm{L}^{-1}$ stock ones. The $1 \mathrm{mg} \mathrm{L}^{-1}$ working stock solution of $\mathrm{Al}(\mathrm{III})$ was obtained by the suitable dilution of the $1000 \mathrm{mg} \mathrm{L}^{-1}$ stock solution in a $2 \mathrm{mmol} \mathrm{L}^{-1}$ solution of SVRS. The $\mathrm{pH}$ was adjusted to $\mathrm{pH} 4.6$ by the addition of acetate buffer and the mixture Al-SVRS was heated for $10 \mathrm{~min}$ at $40{ }^{\circ} \mathrm{C}$ for the completion of the reaction. The acetate buffer $\mathrm{pH} 4.6$ was prepared by a mixture of $5.5 \mathrm{~mL}$ of $2 \mathrm{~mol} \mathrm{~L}^{-1}$ acetic acid and $3.7 \mathrm{~mL}$ of $1 \mathrm{~mol} \mathrm{~L}^{-1}$ ammonia in a $50 \mathrm{~mL}$ volumetric flask. The ammonia buffer $\mathrm{pH} 9.5$ was prepared by a mixture of $10.6 \mathrm{~mL}$ of $1 \mathrm{~mol} \mathrm{~L}^{-1}$ hydrochloric acid and $22.5 \mathrm{~mL}$ of $2 \mathrm{~mol} \mathrm{~L}^{-1}$ ammonia in a $100 \mathrm{~mL}$ volumetric flask. The $\mathrm{pH}$ value of all the buffer solutions was adjusted by adding $1 \mathrm{~mol} \mathrm{~L}^{-1} \mathrm{NaOH}$ or $1 \mathrm{~mol} \mathrm{~L}^{-1} \mathrm{HCl}$. The DTPA supporting electrolyte was composed of $0.05 \mathrm{~mol} \mathrm{~L}^{-1} \mathrm{DTPA}, 2.5 \mathrm{~mol} \mathrm{~L}^{-1}$ sodium nitrate and $0.2 \mathrm{~mol} \mathrm{~L}^{-1}$ sodium acetate. A $0.1 \mathrm{~mol} \mathrm{~L}^{-1}$ dimethylglyoxime solution was prepared by dissolution of $0.2900 \mathrm{~g}$ in $25 \mathrm{~mL}$ of ethanol.

\section{Samples}

Commercial EPO formulations used in this work were the following: Eritromax ${ }^{\circledR}$ (Blausiegel, Cotia, SP, Brazil) injectable solution containing 2000, 4000 and 10000 IU of EPO (excipients: sodium chloride, monobasic sodium fosfate and dibasic sodium fosfate); Alfaepoetina ${ }^{\circledR}$ (Blausiegel, Cotia, SP, Brazil) injectable solution containing $4000 \mathrm{IU}$ of EPO (excipients: human albumin, sodium chloride, sodium citrate and citric acid); HemaxEritron ${ }^{\circledR}$ (Aché, Guarulhos, SP, Brazil) lyophilized powder containing $4000 \mathrm{IU}$ of EPO (excipients: human albumin, mannitol, sodium chloride, monobasic sodium fosfate and dibasic sodium fosfate).

\section{UV irradiation of samples analytical procedure}

The efficiency of the UV irradiation for the EPO sample decomposition was investigated in acidic medium of $\mathrm{H}_{2} \mathrm{SO}_{4}$ and in the presence of $\mathrm{H}_{2} \mathrm{O}_{2}$ for the generation of hydroxyl radicals. The following experimental parameters were investigated in the optimization step using irradiation time ( $0-4 \mathrm{~h}$ ) and volume used of $30 \%(\mathrm{~m} / \mathrm{v}) \mathrm{H}_{2} \mathrm{O}_{2}$ solution. All irradiation experiments were carried out using a final sample volume of $10 \mathrm{~mL}(0.5 \mathrm{~mL}$ EPO $+9.5 \mathrm{~mL}$ water). The samples were added of $\mathrm{H}_{2} \mathrm{SO}_{4}$ and $\mathrm{H}_{2} \mathrm{O}_{2}$ in the beginning of UV irradiation. During the irradiation process, the temperature of the sample solution was maintained 
at $85 \pm 3{ }^{\circ} \mathrm{C}$. After the irradiation, sample solutions were cooled down in a water bath for the subsequent voltammetric analysis of $\mathrm{Al}, \mathrm{Cr}$ and $\mathrm{Ni}$ by AdCSV.

\section{Voltammetric determination of $\mathrm{Al}, \mathrm{Cr}$ and $\mathrm{Ni}$ in EPO samples}

For the Al AdCSV determination, $500 \mu \mathrm{L}$ of EPO sample was added to $9.5 \mathrm{~mL}$ water, followed by the addition of $500 \mu \mathrm{L}$ acetate buffer (pH 4.6) and $250 \mu \mathrm{L}$ of $2 \mathrm{mmol} \mathrm{L}^{-1}$ SVRS. Due to the low formation rate of the Al-SVRS, the solution was heated for $10 \mathrm{~min}$ at $40^{\circ} \mathrm{C}$ in a thermostathized water bath before each AdCSV determination. The Al-SVRS was then deposited at HMDE by applying a potential of $-100 \mathrm{mV}$ in the beginning, scaning from -100 to $-800 \mathrm{mV}$ with a scan rate of $40 \mathrm{mV} \mathrm{s}^{-1}$. The Al concentration was determined by standard additions $(n=3)$ of Al-SVRS complex $1 \mathrm{mg} \mathrm{L}^{-1}$ stock solution.

For the Cr AdCSV determination, $500 \mu \mathrm{L}$ of EPO sample was added to $9.5 \mathrm{~mL}$ water, followed by the addition of $2.5 \mathrm{~mL}$ of a supporting electrolyte composed of $0.05 \mathrm{~mol} \mathrm{~L}^{-1}$ DTPA, $2.5 \mathrm{~mol} \mathrm{~L}^{-1}$ sodium nitrate and $0.2 \mathrm{~mol} \mathrm{~L}^{-1}$ sodium acetate. The final solution $\mathrm{pH}$ was adjusted to 6.2 with a $25 \%(\mathrm{~m} / \mathrm{v}) \mathrm{NaOH}$ solution. The Cr-DTPA complex was then deposited at HMDE by applying a potential of $-1000 \mathrm{mV}$ in the beginning, scaning from -1000 to $-1450 \mathrm{mV}$ with a scan rate of $20 \mathrm{mV} \mathrm{s}^{-1}$. The $\mathrm{Cr}$ concentration was determined by standard additions $(n=3)$ of $1 \mathrm{mg} \mathrm{L}^{-1} \mathrm{Cr}$ stock solution.

For the Ni AdCSV determination, $500 \mu \mathrm{L}$ of EPO sample was added to $9.5 \mathrm{~mL}$ water, followed by the addition of $500 \mu \mathrm{L} \mathrm{NH}_{3} / \mathrm{NH}_{4} \mathrm{Cl}$ buffer $\left(1 \mathrm{~mol} \mathrm{~L}^{-1} \mathrm{HCl}+2 \mathrm{~mol} \mathrm{~L}^{-1}\right.$ $\mathrm{NH}_{3}$ ) and $100 \mu \mathrm{L}$ of $0.1 \mathrm{~mol} \mathrm{~L}^{-1}$ dimethylglyoxime. The final solution $\mathrm{pH}$ was adjusted to 9.5 with a $25 \%(\mathrm{~m} / \mathrm{v})$ $\mathrm{NaOH}$ solution. The Ni-DMG complex was then deposited at HMDE by applying a potential of $-700 \mathrm{mV}$ for $60 \mathrm{~s}$ and the potential was scanned from -700 to $-1300 \mathrm{mV}$. The scan rate was $20 \mathrm{mV} \mathrm{s}^{-1}$. The $\mathrm{Ni}$ concentration was determined by standard additions $(n=3)$ of $1 \mathrm{mg} \mathrm{L}^{-1} \mathrm{Ni}$ stock solution.

\section{Results and Discussion}

\section{Determination of Al, Cr and Ni by AdCSV in EPO samples}

The determination of $\mathrm{Al}, \mathrm{Cr}$ and $\mathrm{Ni}$ by AdCSV has already been described in the literature. ${ }^{13,19-26}$ It is also well known that AdCSV measurements have seriously drawbacks caused by interferences of organic compounds present in samples of complex matrices. In this work, we observed that the determination of $\mathrm{Al}, \mathrm{Cr}$, and $\mathrm{Ni}$ by AdCSV directly in diluted $(1: 10)$ EPO samples was not possible. Considering that EPO structure contains a sequence of 165 aminoacids, ${ }^{11}$ the strong adsorption of organics at HMDE should be firstly eliminated in order to allow the adsoraptive accumulation of metallic complexes. Furthermore, the metallic species should be in a "free" or labile form in order to bind the complexes Al-SVRS, Cr-DTPA and Ni-DMG for the AdCSV measurements. The voltammograms in Figure 1 show the influence of EPO matrix on the AdCSV behavior of $\mathrm{Al}, \mathrm{Cr}$ and $\mathrm{Ni}$. The absence of voltammetric signals as well as the formation of high amounts of foam in the voltammetric cell during the dearation process of solutions evidenced the necessity of a sample decomposition step prior to AdCSV determinations. Even though a small voltammetric signal could be observed for Ni-DMG complex in diluted (1:10) EPO samples (Figure 1C), it was much lower than that obtained for Ni-DMG in pure supporting electrolyte.

Considering the interferences observed for EPO samples on the AdCSV determinations showed in Figure 1, we optimized a decomposition step by using UV irradiation for the photo-decomposition of organic compounds in the sample.

\section{Optimization of the UV photo-decomposition of EPO samples}

It is well known that the UV photo-decomposition of samples takes place through free radical reactions involving the hydroxyl radicals $\left({ }^{\circ} \mathrm{OH}\right) \cdot{ }^{16,27,28} \mathrm{In}$ order to increase the - $\mathrm{OH}$ concentration in solutions, the repetitive addition of $\mathrm{H}_{2} \mathrm{O}_{2}$ during the irradiation process is normally employed. Furthermore, the photo-decomposition of aqueous samples by action of ${ }^{\circ} \mathrm{OH}$ radicals is accelerated when carried out at about $90^{\circ} \mathrm{C}$, since a higher concentration of ${ }^{\circ} \mathrm{OH}$ is formed in this medium. ${ }^{16,19,20,27}$

Since the complete decomposition of the EPO sample was shown to be necessary (Figure 1), the parameter irradiation time and $\mathrm{H}_{2} \mathrm{O}_{2}$ concentration were firstly optimized for 1:10 diluted EPO samples acidified with $20 \mu \mathrm{L}$ of concentrated $\mathrm{H}_{2} \mathrm{SO}_{4}$. Firstly, it could be observed that the irradiation of spiked EPO samples from 0.5 to $6 \mathrm{~h}$ without any addition of $\mathrm{H}_{2} \mathrm{O}_{2}$ was not sufficient for the decomposition of samples prior to AdCSV determinations. Thus, we decided to add $30 \%(\mathrm{~m} / \mathrm{v}) \mathrm{H}_{2} \mathrm{O}_{2}$ to all the samples in the beginning of the irradiation processes, which ranged from 0.5 to $6 \mathrm{~h}$. It was observed that the addition of $\mathrm{H}_{2} \mathrm{O}_{2}$ increased significantly the decomposition of EPO samples. Besides, the form of the voltammograms obtained for the Al-SVRS, Cr-DTPA and Ni-DMG complexes changed, and recovery values for $\mathrm{Al}, \mathrm{Cr}$ and $\mathrm{Ni}$ added to EPO samples increased as well. The best recovery values (92-103\%) in spiked EPO samples were obtained by using the conditions 

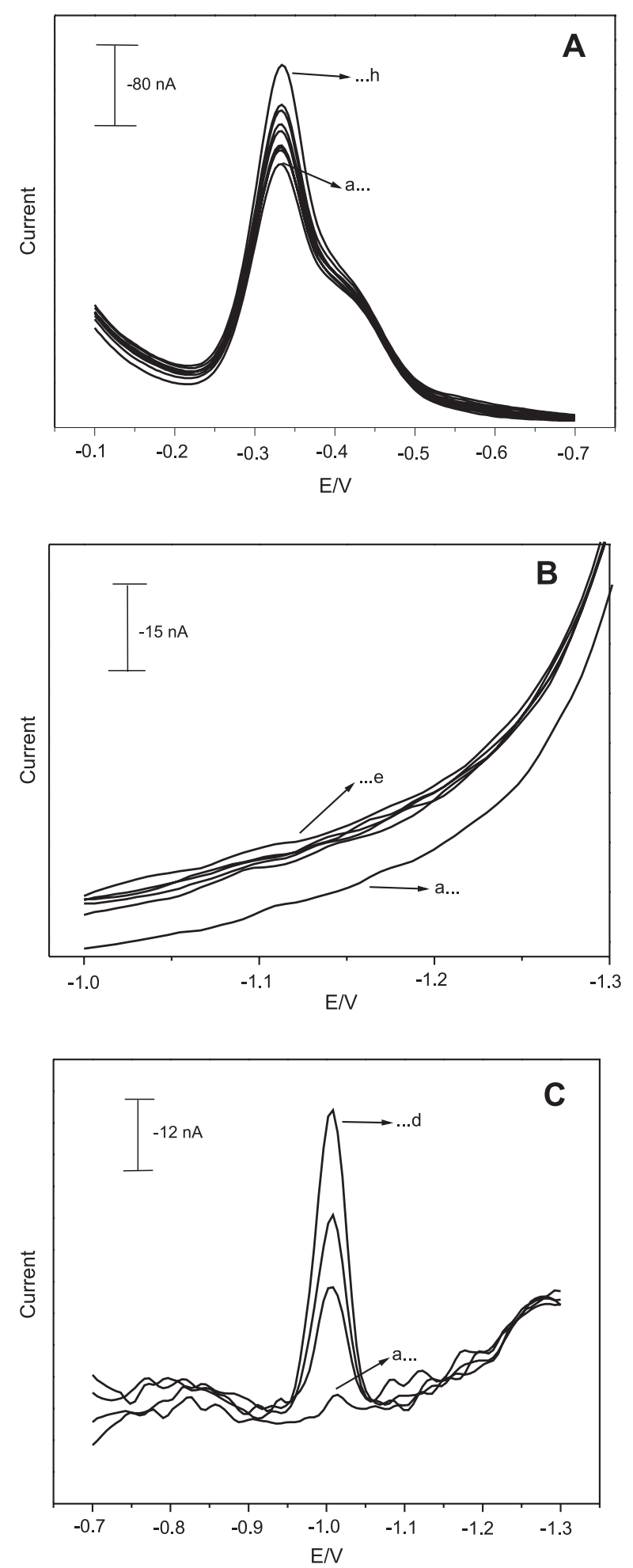

Figure 1. AdCSV behavior of (A) $\mathrm{Al}$, (B) $\mathrm{Cr}$ and (C) $\mathrm{Ni}$ in (a) EPO samples without UV photo-decomposition. (A): standard additions of $\mathrm{Al}$ from (b) $10 \mu \mathrm{g} \mathrm{L} \mathrm{L}^{-1}$ to (h) $80 \mu \mathrm{g} \mathrm{L}{ }^{-1}$; sample solution: $1 \mathrm{~mL}$ EPO in $10 \mathrm{~mL}$ of supporting electrolyte containing $0.05 \mathrm{mmol} \mathrm{L}-1$ SVRS and $0.1 \mathrm{~mol} \mathrm{~L}^{-1}$ acetate buffer ( $\mathrm{pH}$ 4.6). (B): standard additions of $\mathrm{Cr}$ from (b) $1 \mu \mathrm{g} \mathrm{L} \mathrm{L}^{-1}$ to (e) $5 \mu \mathrm{g} \mathrm{L}^{-1}$; sample solution: $1 \mathrm{~mL}$ EPO in $10 \mathrm{~mL}$ of supporting electrolyte containing $0.01 \mathrm{~mol} \mathrm{~L}^{-1}$ DTPA, $0.5 \mathrm{~mol} \mathrm{~L}^{-1} \mathrm{NaNO}_{3}$ and $0.04 \mathrm{~mol} \mathrm{~L}^{-1}$ sodium acetate ( $\mathrm{pH}$ 6.2). (C): standard additions of $\mathrm{Ni}$ from (b) $1 \mu \mathrm{g} \mathrm{L} \mathrm{L}^{-1}$ to (d) $3 \mu \mathrm{g} \mathrm{L}{ }^{-1}$; sample solution: $1 \mathrm{~mL}$ EPO in $10 \mathrm{~mL}$ of supporting electrolyte containing $1 \mathrm{mmol} \mathrm{L}^{-1} \mathrm{DMG}$ and $0.1 \mathrm{~mol} \mathrm{~L}^{-1}$ ammonium buffer ( $\mathrm{pH} 9.5$ ). described in Table 2. The results obtained in the recovey experiments for $\mathrm{Al}, \mathrm{Cr}$ and $\mathrm{Ni}$ under optimized conditions are also summarized in Table 2. The voltammograms in Figure 2 show the AdCSV peaks obtained for $\mathrm{Al}, \mathrm{Cr}$ and $\mathrm{Ni}$ in spiked EPO samples submitted to optimized UV irradiation conditions described in Table 2.

Table 2. Recovery experiments $(n=3)$ for $\mathrm{Al}, \mathrm{Cr}$ and $\mathrm{Ni}$ added to EPO samples (1:10 diluted) submitted to UV irradiation $\left(85 \pm 3^{\circ} \mathrm{C}\right)$

\begin{tabular}{|c|c|c|c|}
\hline Metal & $\begin{array}{l}\text { Metal added to } \\
\text { EPO sample } \\
\left(\mathrm{ng} \mathrm{mL} \mathrm{mL}^{-1}\right)\end{array}$ & $\begin{array}{l}\text { Metal } \\
\text { recovery } \\
(\%)\end{array}$ & UV irradiation conditions \\
\hline \multirow[t]{3}{*}{$\mathrm{Al}$} & 100 & $98 \pm 3$ & \multirow{3}{*}{ 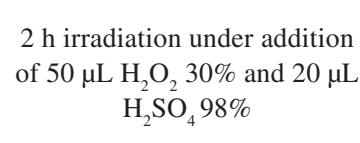 } \\
\hline & 200 & $100 \pm 2$ & \\
\hline & 300 & $95 \pm 3$ & \\
\hline \multirow[t]{3}{*}{$\mathrm{Cr}$} & 20 & $102 \pm 2$ & \multirow{3}{*}{$\begin{array}{c}3 \mathrm{~h} \text { irradiation under addition } \\
\text { of } 50 \mu \mathrm{L} \mathrm{H}_{2} \mathrm{O}_{2} 30 \% \text { and } 20 \mu \mathrm{L} \\
\mathrm{H}_{2} \mathrm{SO}_{4} 98 \% \text { (repeated addition } \\
\text { after } 1.5 \mathrm{~h} \text { irradiation) }\end{array}$} \\
\hline & 40 & $103 \pm 3$ & \\
\hline & 80 & $98 \pm 3$ & \\
\hline \multirow[t]{3}{*}{$\mathrm{Ni}$} & 20 & $93 \pm 2$ & \multirow{3}{*}{ 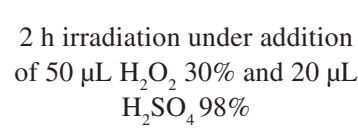 } \\
\hline & 40 & $92 \pm 3$ & \\
\hline & 80 & $95 \pm 3$ & \\
\hline
\end{tabular}

The power of UV radiation source has also been shown to have a strong influence on the decomposition efficiency of samples with high organic content. ${ }^{16}$ In order to investigate the influence of this parameter, we submitted the spiked EPO samples to the UV irradiation process in a home-made UV digestor, which contained a high-pressure mercuy lamp of $400 \mathrm{~W}$ routinely used for public illumination. ${ }^{15}$ As it can be seen in Table 3, lower recovey values (85-96\%) were obtained for $\mathrm{Al}, \mathrm{Cr}$ and $\mathrm{Ni}$ in spiked EPO samples irradiated under the optimized conditions (Table 2 ) by using a $400 \mathrm{~W}$ radiation source. The results in Table 3 show that the $\mathrm{Hg}$ lamp power influences the decomposition efficiency of diluted EPO samples. However, it is possible to use a non-commercial device for decomposition of the samples if the irradiation time is increased to $4 \mathrm{~h}$, where recovery values ranging from 93 to $99 \%$ were obtained for $\mathrm{Al}, \mathrm{Cr}$ and $\mathrm{Ni}$ under the same conditions described in Table 2. Similar results have already been obtained in the photo-decomposition of undiluted urine samples by using the same home-made UV irradiation system described elsewhere. ${ }^{15}$

Interferences on the determination of $\mathrm{Al}, \mathrm{Cr}$ and $\mathrm{Ni}$ by AdCSV in decomposed EPO samples

The influence of some metallic ions on the AdCSV determination of $\mathrm{Al}, \mathrm{Cr}$ and $\mathrm{Ni}$ after $\mathrm{UV}$ photodecomposition was studied in a subsequent step. Possible 
interferences included other electroactive elements with a reduction potential in the region where the complexes Al-SVRS, Cr-DTPA and Ni-DMG are deposited and stripped
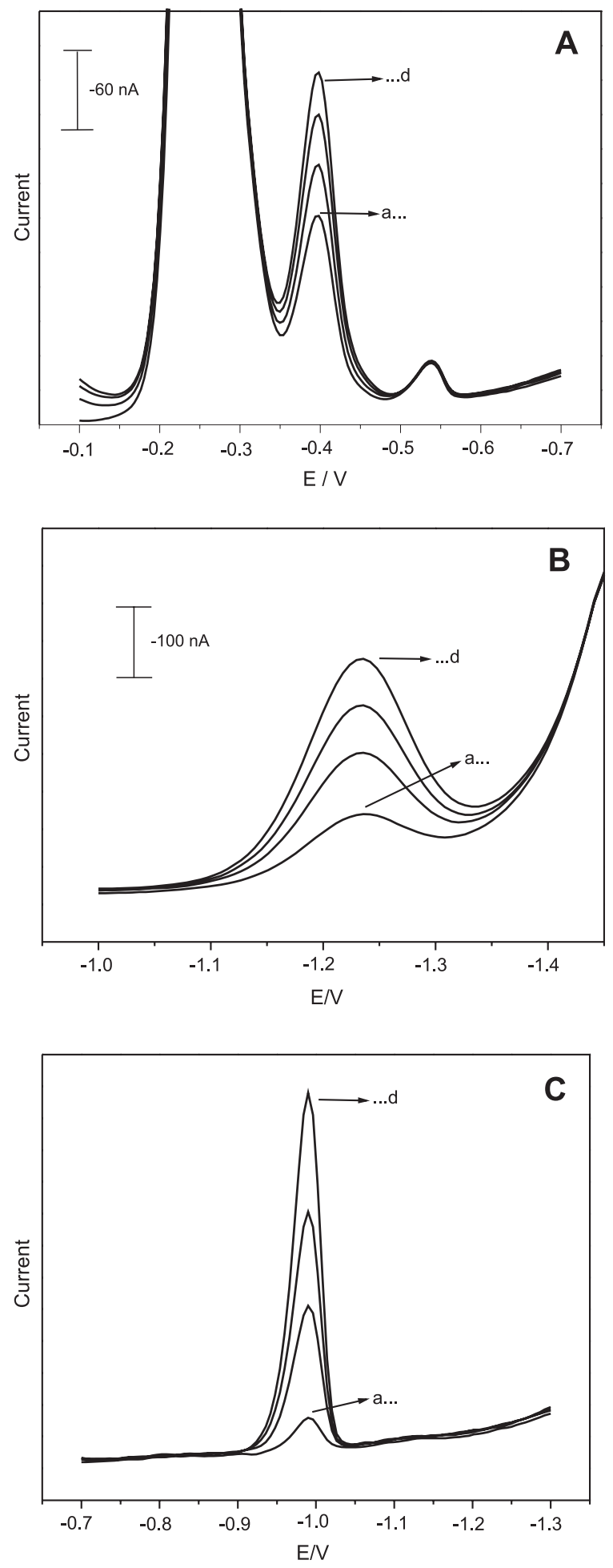

Figure 2. AdCSV behavior of (A) $\mathrm{Al}$ (B) $\mathrm{Cr}$ and (C) $\mathrm{Ni}$ in EPO samples after the optimized UV photo-decomposition step. (a) sample, (b) sample $+10 \mu \mathrm{g} \mathrm{L}^{-1} \mathrm{Al} / 1 \mu \mathrm{g} \mathrm{L}-1 \mathrm{Cr} / 1 \mu \mathrm{g} \mathrm{L}^{-1} \mathrm{Ni}$, (c) sample $+20 \mu \mathrm{g} \mathrm{L}-1 \mathrm{Al} / 2 \mu \mathrm{g} \mathrm{L}^{-1}$ $\mathrm{Cr} / 2 \mu \mathrm{g} \mathrm{L}{ }^{-1} \mathrm{Ni}$ and (d) sample $+30 \mu \mathrm{g} \mathrm{L}^{-1} \mathrm{Al} / 3 \mu \mathrm{g} \mathrm{L}{ }^{-1} \mathrm{Cr} / 3 \mu \mathrm{g} \mathrm{L}^{-1} \mathrm{Ni}$; other experimental conditions as described in Figure 1 and Table 2.
Table 3. Recovery experiments $(n=3)$ of $\mathrm{Al}, \mathrm{Cr}$ and $\mathrm{Ni}$ after $3 \mathrm{~h} \mathrm{UV}$ irradiation $\left(85 \pm 3^{\circ} \mathrm{C}\right)$ for the comparative study of sample digestion efficiency using different UV irradiation systems; UV irradiation conditions as described in Table 2

\begin{tabular}{lccc}
\hline Metal & $\begin{array}{c}\text { Metal added to EPO } \\
\text { sample (ng mL }\end{array}$ & \multicolumn{2}{c}{ Recovered (\%) } \\
Al & 100 & $92 \pm 3$ & $88 \pm 3$ \\
& 200 & $93 \pm 2$ & $85 \pm 3$ \\
$\mathrm{Cr}$ & 20 & $94 \pm 5$ & $96 \pm 4$ \\
& 40 & $93 \pm 5$ & $87 \pm 3$ \\
$\mathrm{Ni}$ & 20 & $92 \pm 3$ & $86 \pm 3$ \\
& 40 & $93 \pm 3$ & $91 \pm 5$ \\
\hline
\end{tabular}

${ }^{a}$ Mercury high-pressure lamp with $500 \mathrm{~W}$ power (Metrohm UV Digestor); ${ }^{\mathrm{b}}$ Mercury high-pressure lamp with $400 \mathrm{~W}$ power (Home-made UV Digestor). ${ }^{15}$

out as well as metallic ions that can also form complexes with SVRS, DTPA and DMG. Among the interferences, we tested the influence of the metallic ions $\mathrm{Pb}^{\mathrm{II}}, \mathrm{Cd}^{\mathrm{II}}, \mathrm{Cu}^{\mathrm{II}}$, $\mathrm{Zn}^{\mathrm{II}}$ and $\mathrm{Fe}^{\mathrm{III}}$, since they were also shown to be present as contaminants in EPO formulations. Furthermore, $\mathrm{Fe}^{\mathrm{III}}$ ions bound the complex Fe-SVRS under the same conditions described for $\mathrm{Al}^{\mathrm{III}}$, having a peak potential close to $-0.55 \mathrm{~V}$ (Figure $2 \mathrm{~A}$ ). $\mathrm{Zn}^{\mathrm{II}}$ ions were determined in this work by ASV using acetate buffer as supporting electrolyte ${ }^{13,29}$ and their concentrations in decomposed EPO samples were found to be between 1.60 and $5.50 \mu \mathrm{g} \mathrm{mL}^{-1}$. Thus, $\mathrm{Zn}^{\mathrm{II}}$ was considered the main inorganic contaminant of EPO samples and a possible interfering species. $\mathrm{Pb}^{\mathrm{II}}, \mathrm{Cd}^{\mathrm{II}}$ and $\mathrm{Cu}^{\mathrm{II}}$ ions were also found to be present as contaminants in EPO samples at concentrations ranging from 0.08 to $8.8 \mathrm{ng} \mathrm{mL}^{-1}$ and, therefore, they were also considered possible interferents on the AdCSV. The metallic ions $\mathrm{Co}^{\mathrm{II}}$, $\mathrm{Tl}^{\mathrm{I}}, \mathrm{Mn}^{\mathrm{II}}$ and $\mathrm{Sb}^{\mathrm{II}}$ as well as the anions $\mathrm{CrO}_{4}{ }^{2-}, \mathrm{SeO}_{3}{ }^{2-}$, and $\mathrm{AsO}_{3}{ }^{2-}$ are electroactive species that were also investigated. However, they had no interference on the AdCSV for Al, $\mathrm{Cr}$ and $\mathrm{Ni}$ in decomposed EPO samples.

Among the possible contaminants of EPO samples, it can be seen in Figure 3 that only $\mathrm{Pb}^{\mathrm{II}}$ is considered an interferent on the determination of Cr by AdCSV. A decrease of $c a$. $45 \%$ in the Cr-DTPA peak was observed for a small excess of $\mathrm{Pb}^{\mathrm{II}}$ ions in relation to $\mathrm{Cr}^{\mathrm{III}}$ ions in the voltammetric cell containing UV decomposed EPO samples. However, the determination of Cr-DTPA in the presence of $\mathrm{Pb}^{\mathrm{II}}$ ions can be carried out by the standard addition method, which eliminates the $\mathrm{Pb}^{\Pi}$ interference. The interference of $\mathrm{Zn}^{\mathrm{II}}$ ions on the $\mathrm{Al}$ determination by AdCSV was shown to be serious only if the determination is performed by the AdCSV method using 1,2-dihydroxyanthraquinone3 -sulfonicacid (DASA) as complexing agent, as already observed in previous works. ${ }^{7,30}$ 

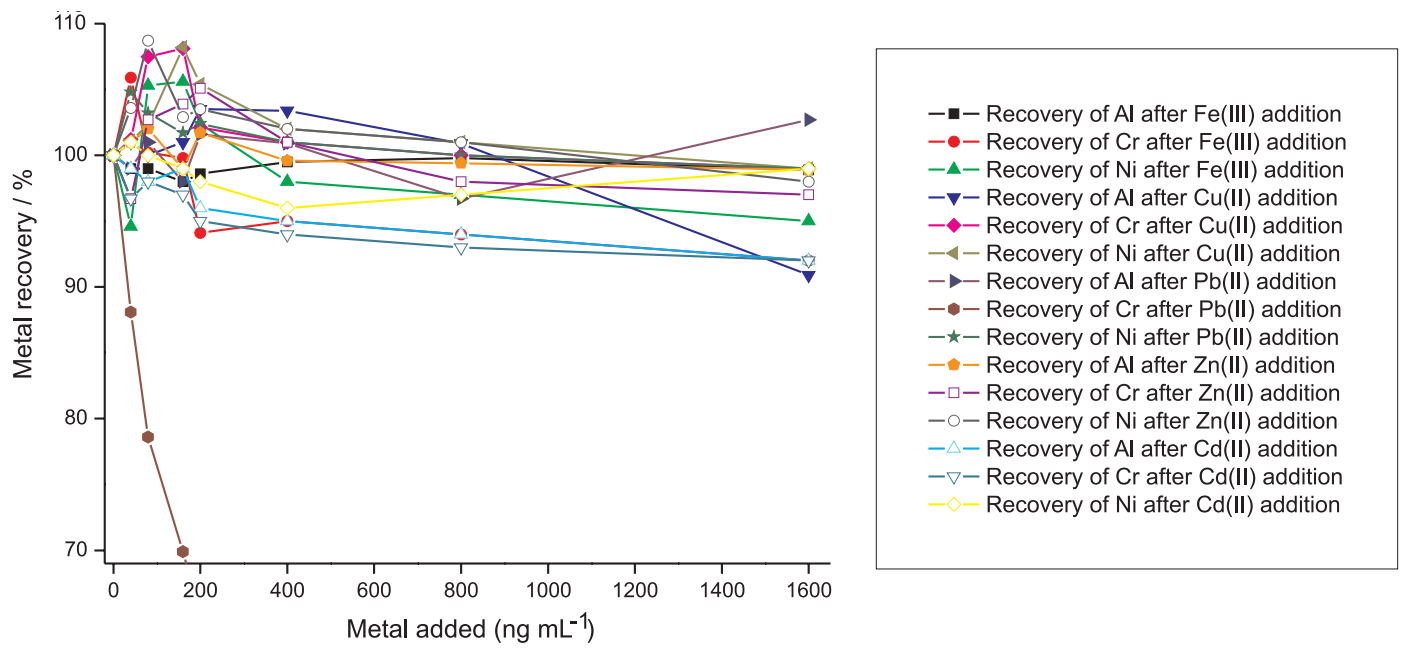

Figure 3. Recovery experiments for $\mathrm{Al}\left(40 \mu \mathrm{g} \mathrm{L}{ }^{-1}\right), \mathrm{Cr}(3 \mu \mathrm{g} \mathrm{L}-1)$ and $\mathrm{Ni}\left(3 \mu \mathrm{g} \mathrm{L}^{-1}\right)$ in the presence of some metallic ions as interfering species in irradiated EPO samples $(n=3)$; UV irradiation conditions as described in Table 2.

\section{Figures of merit}

Linear ranges $(r=0.999)$ for the determination of metals by AdCSV in the voltammetric cell containing $10 \mathrm{~mL}$ of $1: 10$ diluted decomposed EPO samples ranged from 0 to $200 \mu \mathrm{g} \mathrm{L}^{-1}$ for $\mathrm{Al}$ ( $\mathrm{r}=0.999), 0$ to $20 \mu \mathrm{g} \mathrm{L}^{-1}$ for $\mathrm{Cr}(\mathrm{r}=0.997)$ and 0 to $15 \mu \mathrm{g} \mathrm{L}^{-1}$ for $\mathrm{Ni}(\mathrm{r}=0.998)$ using the HMDE as working electrode and a deposition time of $60 \mathrm{~s}$ for $\mathrm{Ni}$. The linear range can be expanded up to $100 \mu \mathrm{g} \mathrm{L}^{-1}$ for $\mathrm{Cr}(\mathrm{r}=0.995)$ if the static mercury drop electrode (SMDE) is used as working electrode.

The following limits of detection for the metals in EPO samples decomposed by UV irradiation were calculated from the $(3 \sigma)$ standard deviation associated with the mean of 10 measurements of the background current divided by the slope of the respective calibration function: ${ }^{31}$ $19.0 \mathrm{ng} \mathrm{mL}^{-1}$ for $\mathrm{Al}, 2.0 \mathrm{ng} \mathrm{mL}^{-1}$ for $\mathrm{Cr}$ and $1.2 \mathrm{ng} \mathrm{mL}^{-1}$ for $\mathrm{Ni}$ (deposition time of $60 \mathrm{~s}$ at the HMDE). The following limits of quantification for the metals in EPO samples decomposed by UV irradiation were calculated from the $(10 \sigma)$ standard deviation associated with the mean of 10 measurements of the background current divided by the slope of the respective calibration function: ${ }^{31} 63.0 \mathrm{ng} \mathrm{mL}^{-1}$ for $\mathrm{Al}, 7.0 \mathrm{ng} \mathrm{mL}^{-1}$ for $\mathrm{Cr}$ and $4.0 \mathrm{ng} \mathrm{mL}^{-1}$ for $\mathrm{Ni}$ (deposition time of $60 \mathrm{~s}$ at the HMDE).

Relative standard deviations calculated for five measurements of the metals in the voltammetric cell containing $10 \mathrm{~mL}$ of 1:10 diluted EPO samples after the UV irradiation step were $2.5 \%$ for $25.0 \mu \mathrm{g} \mathrm{L}^{-1} \mathrm{Al}, 3.5 \%$ for $5.0 \mu \mathrm{g} \mathrm{L}^{-1} \mathrm{Cr}$ and $3.0 \%$ for $5.0 \mu \mathrm{g} \mathrm{L}^{-1} \mathrm{Ni}$.

\section{Analytical application}

The determination of nephrotoxic metals in fluids and medicaments used in the treatment of chronic renal failure is very important, since they are common contaminats of pharmaceutical formulations and inorganic salts added as excipients. The method described above, which combines the decomposition of EPO samples by UV irradiation and the sensitive AdCSV determination of metals, was applied to the determination of $\mathrm{Al}, \mathrm{Cr}$ and $\mathrm{Ni}$ in three different formulations of recombinant human EPO. Twelve different samples of Eritromax $^{\circledR}$ injectable solution, Alfaepoetina ${ }^{\circledR}$ injectable solution and Hemax-Eritron ${ }^{\circledR}$ lyophilized powder were submitted to the UV irradiation step and the metal content was determined by the respective AdCSV method. Table 4 shows the results obtained with three replicate determinations using the standard addition method. According to these results, $\mathrm{Al}$ is present in all the commercial EPO formulations in concentrations ranging from 420.2 to $840.5 \mathrm{ng} \mathrm{mL}^{-1}$ (RSD $2-5 \%$ ), which represents a serious contamination source for patients undergoing renal failure. $\mathrm{Cr}$ is also present as a contaminant in all the EPO formulations in concentrations

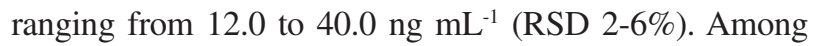
the toxic metals studied here, $\mathrm{Ni}$ was found to be the minor contaminant in all the EPO formulations, being its concentration ranging from 4.1 to $8.2 \mathrm{ng} \mathrm{mL}^{-1}$ (RSD 3-8\%). Table 4 also compares the results obtained in all the EPO formulations analyzed by the proposed AdCSV method and the comparative GFAAS method. As can be seen, the results obtained by AdCSV are in good agreement with those obtained by the comparative GFAAS method for $\mathrm{Al}, \mathrm{Cr}$ and $\mathrm{Ni}$ in some analyzed samples.

\section{Conclusions}

The proposed method provided a sensitive voltammetric determination of $\mathrm{Al}, \mathrm{Cr}$ and $\mathrm{Ni}$ as contaminants of EPO samples used in the treatment of chronic renal failure. The 
Table 4. Determination of $\mathrm{Al}, \mathrm{Cr}$, and $\mathrm{Ni}$ as contaminants in EPO samples by AdCSV and GFAAS after UV irradiation $\left(85 \pm 3^{\circ} \mathrm{C}\right)$; UV irradiation conditions as described in Table 2

\begin{tabular}{lcccccc}
\hline Sample & \multicolumn{5}{c}{ Metal concentration $\left(\mathrm{ng} \mathrm{mL}^{-1}\right)$} \\
& \multicolumn{5}{c}{ Al } & \multicolumn{2}{c}{ Ni } \\
& AdCSV $^{\mathrm{a}}$ & GFAAS $^{\mathrm{b}}$ & AdCSV $^{\mathrm{c}}$ & GFAAS $^{\mathrm{d}}$ & AdCSV $^{\mathrm{e}}$ & GFAAS \\
\hline 1 & 840.0 & 880.1 & 12.0 & 10.5 & 6.0 & $<10.0$ \\
2 & 610.5 & & 40.0 & 42.8 & 5.2 & $<10.0$ \\
3 & 571.0 & 548.8 & 19.0 & 18.3 & 4.3 & $<10.0$ \\
4 & 662.3 & 630.5 & 18.2 & 17.5 & 4.1 & $<10.0$ \\
5 & 840.5 & 890.2 & 21.0 & & 4.1 & $<10.0$ \\
6 & 620.2 & & 25.2 & 27.1 & 6.3 & $<10.0$ \\
7 & 792.5 & 778.4 & 23.1 & & 8.0 & $<10.0$ \\
8 & 652.4 & & 22.2 & 20.4 & 7.2 & $<10.0$ \\
9 & 532.0 & 560.1 & 27.5 & & 8.2 & $<10.0$ \\
10 & 450.3 & & 17.2 & & 7.2 & $<10.0$ \\
11 & 420.2 & & 15.5 & 17.2 & 4.2 & $<10.0$ \\
12 & 470.2 & 450.0 & 22.3 & 24.1 & 5.5 & $<10.0$ \\
\hline
\end{tabular}

${ }^{\mathrm{a}} \operatorname{RSD}(\mathrm{n}=3): 2-5 \% ;{ }^{\mathrm{b}} \operatorname{RSD}(\mathrm{n}=3): 3-8 \% ;{ }^{\mathrm{c}} \operatorname{RSD}(\mathrm{n}=3): 2-6 \% ;{ }^{\mathrm{d}} \operatorname{RSD}$ $(\mathrm{n}=3): 4-9 \%$; ${ }^{\mathrm{e} S D}(\mathrm{n}=3): 3-8 \%$.

developed decomposition step for EPO samples using UV irradiation was shown to be efficient for eliminating the matrix interferences observed on the AdCSV determination. The irradiation of acidified EPO samples from 2 to $3 \mathrm{~h}$ in the presence of $\mathrm{H}_{2} \mathrm{O}_{2}$ allowed the efficient decomposition and the determination of contaminants without matrix interferences. The method was shown to be free of interferences from other metallic species, which can be present as contaminants in the samples. Contamination levels observed for $\mathrm{Al}, \mathrm{Cr}$ and $\mathrm{Ni}$ differed significantly, being $\mathrm{Al}$ the main contaminant among the studied toxic metals. The studied nephrotoxic metals were found to be present in all the EPO formulations in concentrations from 4.1 to $840.5 \mathrm{ng} \mathrm{mL}^{-1}$, representing a serious contamination source for anemic patients undergoing chronic renal failure.

\section{Acknowledgments}

The authors wish to acknowledge fellowships awarded by the Brazilian foundations CAPES/DAAD (PROBRAL No. 240/06), CNPq (process No. 478215/2007-0) and FAPERGS. The authors also express their grateful thanks to Metrohm AG Company (Herisau, Switzerland) for the financial support of this work.

\section{References}

1. Lee, S. H.; Huang, J. W.; Hung, K. Y.; Leu, L. J.; Kan, Y. T.; Yang, C. S.; Wu, D. C.; Huang, C. L.; Chen, P. Y.; Chen, J. S.; Chen, W. Y.; Artificial Organs 2000, 24, 841.
2. Carvalho, L. M.; Nascimento, P. C.; Bohrer, D.; Stefanello, R.; Pilau, E. J.; Electroanalysis 2008, 20, 776.

3. Carvalho, L. M.; Nascimento, P. C.; Bohrer, D.; Pilau, E. J.; Stefanello, R.; Lauer, M.; Electroanalysis 2006, 18, 1081.

4. Bohrer, D.; Bertagnolli, D.; Oliveira, S. M. R.; Nascimento, P. C.; Carvalho, L. M.; Pomblum, S. G.; Nephrol. Dial. Transplant 2007, 22, 605.

5. Carvalho, L. M.; Nascimento, P. C.; Koschinsky, A.; Bau, M.; Stefanello, R.; Spengler, C.; Bohrer, D.; Jost, C.; Electroanalysis 2007, 19, 1719.

6. Nascimento, P. C.; Bohrer, D.; Carvalho, L. M.; Caon, C. E.; Pilau, E.; Vendrame, Z. B.; Stefanello, R.; Talanta 2005, 65, 954.

7. Carvalho, L. M.; Nascimento, P. C.; Bohrer, D.; Stefanello, R.; Bertagnolli, D.; Anal. Chim. Acta 2005, 546, 79.

8. Bohrer, D.; Nascimento, P. C.; Guterres, M.; Seibert, E.; Trevisan, M.; Analyst 1999, 124, 1345.

9. Bohrer, D.; Nascimento, P. C.; Gioda, A.; Binotto, R.; Anal. Chim. Acta 1998, 362, 163.

10. Lima, D.; Manual de Farmacologia Clínica, Terapêutica e Toxicologia, Guanabara Koogan: Rio de Janeiro, Brasil, 1992.

11. Korolkovas, A.; Dicionário Terapêutico, $6^{\text {th }}$ ed., Guanabara Koogan: Rio de Janeiro, Brasil, 1999.

12. Eisenbrand, G.; Metzler, M.; Toxikologie für Naturwissenschaftler und Mediziner, Thieme: Stuttgart, 2001.

13. Henze, G.; Polarographie und Voltammetrie: Grundlagen und Analytische Praxis, Springer-Verlag: Berlin, 2001.

14. Scholz, F.; Electrochemical Methods: Guide to Experiments and Applications, Springer-Verlag: Berlin, 2005.

15. Carvalho, L. M.; Nascimento, P. C.; Bohrer, D.; Spengler, C.; Garmatz, J. C.; Del-Fabro, L.; Bolli, A. A.; Garcia, S. C.; Moro, A. M.; da Rosa, M. B.; Quim. Nova 2008, 31, 1336.

16. Golimowski, J.; Golimowski, K.; Anal. Chim. Acta 1996, 325, 111.

17. Harris, D.; Análise Química Quantitativa, $6^{\text {th }}$ ed., LTC Livros Técnicos e Científicos Editora S.A.: Rio de Janeiro, Brasil, 2005.

18. Vogel, A.; Análise Química Quantitativa , $6^{\text {th }}$ ed., LTC Livros Técnicos e Científicos Editora S.A.: Rio de Janeiro, Brasil, 2002.

19. Boussemart, M.; van den Berg, C. M. G.; Ghaddaf, M.; Anal. Chim. Acta 1992, 262, 103.

20. Meyer, A.; Neeb, R.; Fresenius Z. Anal. Chem. 1983, 315, 118.

21. Li, Y.; Xue, H.; Anal. Chim. Acta 2001, 448, 121.

22. Kiptoo, J. K.; Ngila, J. C.; Sawula, G. M.; Talanta 2004, 64, 54.

23. Arancibia, V.; Muñoz, C.; Talanta 2007, 73, 546.

24. Thomas, S. D.; Davey, D. E.; Mulcahy, D. E.; Chow, C. W. K.; Electroanalysis 2006, 18, 2257.

25. Rezaei, B.; Rezaei, E.; J. Anal. Chem. 2006, 61, 262.

26. Hutton, E. A.; Ogorevc, B.; Hočvar, S. B.; Smyth, M. R.; Anal. Chim. Acta 2006, 557, 57.

27. Achterberg, E. P.; Braungardt, C. B.; Sandford, R. C.; Worsfold, P. J.; Anal. Chim. Acta 2001, 440, 27. 
28. Achterberg, E. P.; van den Berg, C. M. G.; Anal. Chim. Acta 1994, 291, 213.

29. DIN 38406 Teil 16, Verfahren zur Bestimmung von Zink, Cadmium, Blei, Kupfer, Thallium, Nickel, Cobalt mittels Voltammetrie - E16 Deutsche Einheitsverfahren; http://www. din.de/cmd?level=tpl-home\&contextid=din, accessed in June 2009 .
30. van den Berg, C. M. G.; Murphy, K.; Riley, J. P.; Anal. Chim. Acta 1986, 188, 177.

31. Hasebe, K.; Osteryoung, J.; Anal. Chem. 1975, 47, 2412.

Received: June 4, 2009

Web Release Date: December 21, 2009 